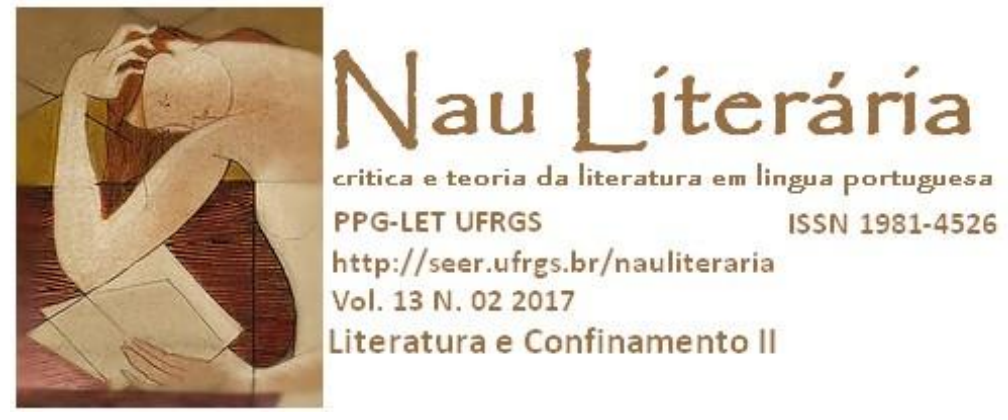

\title{
A intertextualidade nos romances engajados de língua portuguesa
}

Donizeth Aparecido Santos

Resumo: O artigo apresenta uma abordagem da intertextualidade presente nos romances engajados de língua portuguesa publicados a partir da década de 30 do século XX. Um diálogo desencadeado por uma afinidade ideológica entre os escritores que se viam como companheiros numa mesma trincheira, lutando contra a alienação, a violência, a injustiça e a miséria humana. Com o objetivo de tornar o mundo um pouco melhor, tendo como arma a palavra literária. Essa afinidade ideológica levou os romancistas engajados brasileiros e portugueses a uma afinidade estética, que resultou na apropriação de temas e técnicas narrativas pelos segundos em relação aos primeiros. Posteriormente, já na segunda metade do século, os escritores africanos de língua portuguesa (angolanos, cabo-verdianos e moçambicanos) vão se identificar com a literatura produzida pelos modernistas brasileiros e neorrealistas portugueses e vão utilizar as suas formas literárias como modelos para construir uma literatura nacional.

Palavras-chave: Literaturas de língua portuguesa; Literatura e engajamento; Literatura e política.

Abstract: The article presents an approach of intertextuality present on engaged novels of Portuguese Language published from decade 30 of XX century a triggered dialogue by an infinity range of ideology between the writers who saw themselves as partners in the same trench, struggling against alienation, violence, injustice and human misery aiming to become the world a better place, Taking the word literary as a weapon. This ideological affinity led the Brazilian and Portuguese people engaged novelists to the aesthetic affinity that results in themes appropriation and narratives techniques by the seconds in relation to the firsts and after in its second half century the Portuguese Language writers from Africa (Angolans, Cape Verde's Citizens and Mozambicans) were going to identify themselves with literature produced by Brazilian Modernist and Portuguese Neorealist and were going to use their literary forms as models to construct a national literature.

Keywords: Literatures of Portuguese Language; Literature and engagement; Literature and politcs.

\section{A intertextualidade}

Segundo Julia Kristeva (1974), para Bakhtin a palavra literária é um cruzamento de superfícies textuais, em que se realiza um diálogo entre diversas estruturas: o escritor, o destinatário e o contexto cultural atual ou anterior.

Nesse sentido, o texto literário situa-se numa corrente histórica e social, constituída por textos que o escritor lê e na qual se insere ao reescrevê-los. Logo ocorre a transformação 
da diacronia em sincronia, e à luz dela a história linear revela-se uma abstração. Dessa forma, o escritor participa da história literária através de uma escritura-leitura que transgride essa abstração. Assim, o texto literário produzido é uma prática de uma estrutura significante que se realiza em função ou em oposição à outra estrutura.

A partir das considerações de Mikhail Bakhtin, Julia Kristeva estabelece uma concepção espacial do funcionamento poético da linguagem e define três dimensões do espaço textual, onde os diferentes diálogos se realizam através das operações dos conjuntos sêmicos e das sequências poéticas:

Essas três dimensões são: o sujeito da escritura, o destinatário e os textos exteriores (três elementos em diálogo). O estatuto da palavra define-se, então, a) horizontalmente: a palavra no texto pertence simultaneamente ao sujeito da escritura e ao destinatário, e b) verticalmente: a palavra no texto está orientada para o corpus literário anterior ao sincrônico. (KRISTEVA, 1974, p. 63).

Kristeva ressalta que. nesse universo discursivo. o destinatário consta apenas como discurso, fundindo-se, então, ao outro discurso (o outro livro), àquele em relação ao qual o escritor escreveu seu texto, de forma "que o eixo horizontal (sujeito-destinatário) e o eixo vertical (texto-contexto) coincidem para revelar um fato maior: a palavra (o texto) é um cruzamento de palavras (de textos), onde se lê, pelo menos uma outra palavra (texto)" (KRISTEVA, 1974, p. 64).

Lembrando que em Bakhtin esses dois eixos, denominados de "diálogo" e “ambivalência", não estão claramente distintos, ela ressalta que isso não tira a importância da descoberta que o teórico russo introduz na teoria literária:

Todo texto se constrói como mosaico de citações, todo texto é absorção e transformação de um outro texto. Em lugar da noção de intersubjetividade, instala-se a de intertextualidade e a linguagem poética lê-se pelo menos como dupla. (KRISTEVA, 1974, p. 64)

Dessa forma, Kristeva cria o termo "intertextualidade" para melhor definir a designação do dialogismo bakhtiniano da escritura simultaneamente considerada como subjetividade e comunicabilidade. Por conta desse diálogo, a noção de "pessoa-sujeito da escritura" desaparece para ceder o espaço para a da "ambivalência da escritura", observando que este termo implica a recíproca inserção da história no texto e do texto na história, como duas vias que se unem na narrativa.

Assim, para Bakhtin, na leitura de Julia Kristeva, a escrita de um texto literário é a leitura do corpus literário anterior, noção que implica ver o texto como absorção e réplica a 
outro texto. Utilizando-se, também, do conceito de paragrama, do linguista Ferdinand de Saussure, ela reforça essa concepção do texto literário como escritura-leitura:

O texto literário se insere no conjunto dos textos: é uma escritura-réplica (função ou negação) de um outro (dos outros textos). Pelo seu modo de escrever, lendo o corpus literário anterior ou sincrônico, o autor vive na história e a sociedade se escreve no texto. A ciência paragramática deve, pois, levar em conta uma ambivalência: a linguagem poética é um diálogo de dois discursos. Um texto estranho entra na rede da escritura: esta o absorve segundo leis que estão por descobrir. Assim, no paragrama de um texto, funcionam todos os textos do espaço lido pelo escritor. (KRISTEVA, 1974, p. 98)

Para reforçar essa concepção, Julia Kristeva lembra o significado que o verbo "ler" tinha na antiguidade, um significado que ficou esquecido e que vem ao encontro da conceituação de dialogismo e de intertextualidade:

O verbo "ler" tinha, para os antigos, uma significação que merece ser lembrada e valorizada, com vistas a uma compreensão da prática literária. "Ler" era também "recolher", "colher", "espiar", "reconhecer os traços”, "tomar", "roubar". "Ler" denota, pois, uma participação agressiva, uma apropriação ativa do outro. "Escrever" seria o "ler" convertido em produção, indústria: a escritura-leitura, a escritura paragramática seria a aspiração de uma agressividade e uma participação total. (KRISTEVA, 1974, p. 98)

Nesse aspecto, para Kristeva, a linguagem poética (literária) se constrói por meio de um diálogo de textos em que toda sequência se constrói em relação à outra, oriunda de um outro corpus. De forma que ela é duplamente orientada: primeiro, para o ato de reminiscência, que é a evocação de outra escrita; e, segundo, para o ato de intimação, que é a transformação da escrita evocada. Nesse sentido, um livro remete a outros livros e confere a eles um novo modo de ser, elaborando também a sua própria significação.

O conceito de intertextualidade concebido por Julia Kristeva ajusta-se perfeitamente quando pensamos em abordar o diálogo entre os escritores engajados de língua portuguesa, ocorrido no século XX.

\section{A literatura engajada}

A literatura engajada, tal como nós a conhecemos hoje, é um fenômeno do século XX, embora o sentido de engajamento esteja presente na literatura desde a antiguidade. Ela se desenvolveu no período histórico mais conturbado que a humanidade já teve na era moderna, o chamado período entreguerras. Além das duas grandes guerras mundiais, que lhe serviu de moldura, também abrigou em seu bojo a Revolução Russa de 1917. Esta, embasada na teoria de Karl Marx, apresentou um novo modelo de sociedade para o mundo, que, por sua vez, trouxe entusiasmadas adesões como também vigorosos repúdios. Também não podemos 
esquecer que nesse período, além do comunismo soviético, houve a emergência de regimes autoritários de extrema direita: o fascismo italiano e espanhol e o nazismo alemão, responsáveis diretos pela Guerra Civil Espanhola e a Segunda Guerra Mundial. Todos esses elementos históricos, políticos e sociais serviram de matéria-prima para o desenvolvimento da literatura engajada.

Dessa forma, o aparecimento de ideologias e regimes políticos antagônicos transformou a Europa num campo marcado pelas discussões ideológicas que, por vezes, levaram as principais nações europeias ao conflito armado, vitimando dezenas de milhões de pessoas, seja pela violência direta da guerra, seja pela fome e doença causadas por ela. Diante de tal cenário desolador, surge uma literatura comprometida com o ser humano, denunciando a violência, a fome e a injustiça disseminadas tanto por regimes políticos autoritários quanto por regimes capitalistas democráticos.

Nesse sentido, segundo Benoît Denis (2002), a literatura engajada é um fenômeno historicamente situado - associado a Jean-Paul Sartre, seu principal teorizador e defensor - e à emergência no pós-guerra de uma literatura preocupada com as questões políticas e sociais e também desejosa de mudar o mundo, a partir do modelo ideológico da Revolução Russa de 1917. Dessa forma, o autor considera-a como a literatura de combate produzida no século XX, tomando como ponto de partida o caso Dreyfus e, ponto de chegada, o final desse mesmo século, pelo fato de que "é com efeito durante esse período que essa problemática se desenvolveu e foi formulada com precisão, que ela tomou essa denominação e que se se tornou num dos eixos maiores do debate literário" (DENIS, 2002, p. 11). Assim, ele delimita o termo "literatura engajada" a um período histórico em que havia elementos comuns entre os escritores considerados engajados, laços criados pelo próprio contexto histórico-políticosocial em que viviam.

É preciso [...] partir da literatura engajada tal como ela se apresentou no século XX: o engajamento sendo discutido e se definindo ao longo desse século, adquiriu um valor transhistórico e tornou-se numa possibilidade literária suscetível de se aplicar a outros momentos ou outras épocas da história literária. É, portanto, a partir do modo como ele foi pensado por Sartre e os seus contemporâneos, que se pode tentar retornar no tempo e examinar de que maneira escritores ou homens de letras quiseram desenvolver uma concepção e uma prática "engajada" de escritura, num tempo em que a noção de engajamento não existia como tal.

Ter-se-á, portanto, definido: para nós, a literatura engajada pareceu antes de tudo historicamente situada. (DENIS, 2002, p. 19)

Outro elemento importante da literatura engajada é que ela é, antes de tudo, literatura. Ou seja, ela é primeiramente ficção, um objeto estético que internaliza o fator político-social, transformando-o num elemento importante em sua estrutura, conforme assertiva de Antonio 
Candido (2000) sobre os fatores externos que condicionam a obra literária. Nesse sentido, o campo da política possibilita a ela realizar uma retomada total do mundo, pois, conforme pensa Jean-Paul Sartre (2006), é tarefa do escritor "fazer entrever os valores de eternidade que estão implicados nos debates sociais e políticos", de forma que ela é uma literatura portadora de um discurso político, sem, no entanto, que o elemento político predomine sobre o literário. De acordo com Benoît Denis:

Contrariamente a uma opinião difundida, a literatura engajada não é antes de tudo política; ela só o é em virtude de uma necessidade secundária, que quer que as questões morais ou éticas, colocadas concretamente e coletivamente desemboquem quase inevitavelmente em considerações políticas [...]. (DENIS, 2002, p. 36)

Embora exista um teatro engajado e uma poesia engajada, é no romance que a literatura engajada encontrou território fértil para se desenvolver. Uma das principais causas dessa predisposição para o engajamento foi a incorporação do "realismo formal" feita pelo romance no século XIX. O realismo formal é o termo cunhado por Ian Watt (1990) para designar um modo de composição narrativa em que a realidade e suas implicações históricas, políticas e sociais são reelaboradas artisticamente. Edvaldo Bergamo (2008), tomando por base o pensamento de Ian Watt, afirma que o realismo formal, ou método realista, conforme ele próprio prefere denominar, tornou-se um valioso instrumento de análise histórica da sociedade. Assim, propiciou o desenvolvimento do romance, tornando-o um veículo de expressão da realidade e um relato verossímil da experiência social e individual no período da consolidação da burguesia.

Conforme nos aponta Benoît Denis (2002, p. 87-88), a estética realista, que se conduz por essa forma de composição narrativa, possui uma vocação totalizante que dá "o suporte ideal de uma representação engajada do real e da História”. Desse modo, o romance realista representa o real, reconstruindo-o, organizando-o e interpretando-o, num processo denominado de “mediação” por Raymond Willians (1979), através do qual o real, o conteúdo histórico-político-social é formulado artisticamente, transformando-se num objeto estético.

O romance engajado do século XX é um herdeiro direto da tradição realista, pelo fato de, a exemplo do seu antecessor, ser "portador de uma veemente ação crítica contra o meio social, ao expor aquilo que está escondido sob as malhas de uma conjuntura histórica opressora e reificadora” (BERGAMO, 2008, p. 44), ou seja, ele apresenta à sociedade uma imagem infeliz dela mesma, conforme o pensamento de Sartre (2006). O que os diferencia são que os eventos ocorridos no decorrer do século XX - principalmente a Revolução Russa, as duas Guerras Mundiais, a Guerra Civil Espanhola e os regimes autoritários, no período do 
entreguerras - fazem com que o romancista, espremido entre ideologias antagônicas, sinta mais o peso da história, gerando a necessidade de maior participação social e política, com vistas ao combate da alienação, opressão e violência promovidas pelas guerras e pelos governos totalitários.

É sob o peso dessa carga histórica do seu tempo que o romancista da primeira metade do século XX, pressionado pelas ideologias de direita, de centro e de esquerda, sente a necessidade urgente de tomar partido frente às questões cruciais pelas quais o mundo atravessa. Assim, há a tomada de posição refletida, lúcida e voluntária que, no plano literário, vai exigir do escritor uma radicalidade ética acompanhada de uma radicalidade estética. Pelo fato de os escritores engajados terem o comprometimento humanitário como linha-mestra de seus projetos literários, possuírem uma mentalidade antiburguesa (embora muitos deles sejam burgueses), serem resistentes à ideologia dominante - contrários, principalmente, às ideologias nazista e fascista -, possibilitou entre eles um intenso diálogo no campo literário.

Dessa forma, as afinidades ideológicas entre os romancistas engajados vão convergir também em afinidades estéticas, por meio da apropriação de técnicas narrativas inovadoras realizadas entre eles, de modo que elas se tornaram quase um patrimônio comum da literatura da primeira metade do século XX.

\section{0 romance engajado de língua portuguesa}

O romance engajado em língua portuguesa, produzido no Brasil a partir dos anos $30 \mathrm{e}$ em Portugal a partir da década de 40, conforme nos aponta Edvaldo Bergamo (2008, p. 52), notabilizou-se pelo compromisso ideológico de "denunciar as injustiças sociais e as contradições político-econômicas, registrando a marginalização e a degradação do espoliado" nas sociedades brasileira e portuguesa, consideradas historicamente injustas pelos escritores engajados. Nesse sentido, Bergamo elenca as principais características dessa produção literária que foi predominante entre as décadas de 30 e 50 nas literaturas de língua portuguesa:

\footnotetext{
Em linhas gerais, o romance engajado dos anos 30 e 40 do século XX define-se pelas seguintes características: expressão de convicto comprometimento político do intelectual, concepção materialista da existência, apresentação de camadas sociais oprimidas como matéria ficcional, consideração do indivíduo sob uma perspectiva de classe, análise dos meios de produção existentes e sentido teleológico que implica a confiança no homem e a certeza da superação das adversidades encontradas. (BERGAMO, 2008, p. 198-199)
}

Conforme afirmamos anteriormente, o romance engajado em língua portuguesa surge primeiramente no Brasil nos anos 30 e só na década seguinte vai ter os seus representantes em 
Portugal. De 1930 a 1939 é possível identificar na chamada literatura de ênfase social brasileira quase 30 romances com as características de literatura engajada. Nesse período, Amando Fontes publicou Os corumbás e A lua do Siriri; Erico Veríssimo: Clarissa, Música ao longe, Caminhos cruzados, Um lugar ao sol e Olhai os lírios do campo; Graciliano Ramos: Caetés, São Bernardo, Angústia e Vidas secas; Jorge Amado: País do Carnaval, Cacau, Suor, Jubiabá, Mar morto e Capitães de areia; José Lins do Rego: Menino de engenho, Doidinho, Banguê, Moleque Ricardo, Usina, Pureza, Pedra bonita e Riacho doce; e Rachel de Queiroz: O quinze, João Miguel, Caminho de pedras e As três Marias. Não podemos esquecer também o romance A bagaceira, de José Américo de Almeida, publicado em 1928, tido como o iniciador do romance social brasileiro dos anos 30.

Embora nem todos eles expressem um conteúdo político explícito, ou mesmo possuam todas as características do romance engajado de língua portuguesa, elencadas na citação anterior de Edvaldo Bergamo, todos apresentam uma preocupação com o aspecto social da realidade brasileira e o destino do ser humano. Isso mostra aquilo que Jean-Paul Sartre (2006) denomina de "o paradoxo que é o homem no mundo", que caracteriza, de um modo geral, a literatura engajada, pois essa escolha culmina no desvendamento do mundo ao leitor, nesse caso específico, o desvendamento da realidade social brasileira. A publicação de romances brasileiros engajados adentra pelas décadas seguintes, nas quais novas obras são publicadas e novos escritores surgem, indo até o período da ditadura militar, nos anos 60 e 70.

Aqui é importante lembrar que o romance imbuído de abordagem social não é uma novidade da literatura brasileira dos anos 30, pois ela já existia nos romances naturalistas e na ficção de Lima Barreto. Segundo Antonio Candido (2006), o que diferencia esses romancistas da ficção naturalista é a superação do otimismo patriótico e a adoção de um tipo de pessimismo feita por eles. Assim, enquanto o Naturalismo

focalizava o homem pobre como elemento refratário ao progresso, eles desvendavam a sua situação na sua complexidade, voltando-se contra as classes dominantes e vendo na degradação do homem uma consequência da espoliação econômica, não do seu destino individual. (CANDIDO, 2006, p. 160)

Há que se ressaltar também que essa literatura é herdeira direta das conquistas formais e ideológicas realizadas pelos modernistas de 22. Conforme Edvaldo Bergamo (2008), ela é fruto da conciliação dessas conquistas com as reivindicações sociais da década de 30, juntamente com a retomada de algumas premissas do realismo do século XIX.

Esses romances, abordando várias faces da realidade brasileira, foram lidos pelos portugueses. Essa leitura ajudou na emergência de uma literatura portuguesa também 
engajada, em contraposição à estética literária defendida pelos integrantes da Revista Presença, na época predominante na cena literária portuguesa. Segundo informação de Benjamin Abdala Júnior (2003), o poeta Ribeiro Couto, adido cultural da embaixada brasileira em Lisboa, foi o responsável por levar os intelectuais portugueses à leitura dos brasileiros.

A leitura dos romancistas brasileiros foi a revelação de um modo novo de se fazer romance para os portugueses, diferente da maneira a qual estavam habituados na época, de forma a indicar um caminho que a ficção portuguesa poderia trilhar, conforme atesta a declaração de António Ramos de Almeida:

Os romances de Graciliano Ramos, José Américo de Almeida, José Lins do Rego, Jorge Amado, Amando Fontes, Raquel de Queirós (sic), Erico Veríssimo chegavam de chofre como um duche sobre uma sensibilidade leitora e crítica embutada pelo decadentismo mórbido do romance europeu que usara e abusara das escavações psicológicas. O romance brasileiro irrompia como qualquer coisa de diferente, repleto de força e de vida de um humanismo novo, onde os problemas concretos e reais da sociedade e do indivíduo se misturaram uns nos outros como os cipós da vegetação selvática. [...] A vida social do Brasil [...] aparecia num realismo direto e espontâneo aos olhos dos leitores e dos escritores portugueses habituados a literatismo convencional do romance francês, onde nos casos individuais, patológicos, isolados, decadentes, ímpares se repetiam aleatórios e vários, já sem o conteúdo ou interesse universal. Nada de admirar, portanto, que a sua experiência tivesse resultado fecunda entre nós, que tivesse sido aproveitada pelos nossos mais novéis e conscientes ficcionistas como um caminho a trilhar, como uma "picada" aberta a golpes de heroísmo através da mata virgem e hostil. (ALMEIDA, 1965, p. 3)

Ainda sobre a impressão causada pelos romances brasileiros em Portugal, Adolfo Casais Monteiro (1964) observa que o interesse por eles era por conta dos tipos humanos que essa literatura revelava, um quadro humano muito diferente do português, devido à grande miscigenação racial e cultural e pelo referver de várias forças sociais, reveladas numa época em que a unidade do povo brasileiro era um processo vivo. Mas, acrescenta ele, a mais forte impressão gerada em seus espíritos foi a maneira com que os romancistas brasileiros souberam arrancar da sua época uma visão profundamente humana e múltipla do mundo.

Nesse sentido, a década de 40 vai ser marcada em Portugal pelo surgimento de uma nova estética literária: o Neorrealismo português, cujo marco inicial é a publicação do romance Gaibéus, por Alves Redol, em dezembro de 1939¹. Levando-se em conta apenas os principais nomes do movimento, só nesse período foram publicados os romances Marés, Avieiros, Fanga e Porto Manso por Alves Redol; A tempestade, A lã e a neve e A curva da estrada, por Ferreira de Castro; Casa da duna, Alcateia e Pequenos burgueses por Carlos de Oliveira; Cerromaior por Manuel da Fonseca; Casa da malta, Minas de S. Francisco e A

\footnotetext{
${ }^{1}$ Antes dessa data, Ferreira de Castro publicou os romances Os emigrantes (1928), A selva (1930), Eternidade (1933) e Terra fria (1935). Por isso, o romancista é considerado um neorrealista e um precursor do movimento.
} 
noite e a madrugada por Fernando Namora; Esteiros por Soeiro Gomes; Vagão J e Mudança por Vergílio Ferreira. A exemplo do romance engajado brasileiro, o português também adentra as décadas seguintes, indo até o início da década de 80, quando José Saramago publica um romance como Levantado do chão.

Vale lembrar que na época as condições históricas e políticas vividas por portugueses e brasileiros eram muito semelhantes, as quais foram determinantes para a formação dos romancistas engajados dos dois países, refletindo-se diretamente em seus romances. Portugal contava, desde 1927, com o Estado Novo de António Salazar, um regime político de contornos fascistas; enquanto no Brasil a Revolução de 30, de início com ideais democráticos, em 1937, se tornaria um regime autoritário, o Estado Novo de Getúlio Vargas, também com uma ideologia muito próxima do fascismo. Ainda não podemos esquecer que, no mesmo período, a ameaça nazista e a franca ascensão do fascismo pela Europa gerava uma preocupação constante com o destino da humanidade. Nesse sentido, Edvaldo Bergamo, analisando o diálogo estabelecido entre romancistas brasileiros e portugueses do período, faz a seguinte observação:

O contexto histórico e estético da década de 30 e a orientação política preferencialmente de esquerda aproximaram diversos romancistas brasileiros como Jorge Amado, Amando Fontes, Erico Veríssimo, José Lins do Rego, Rachel de Queiroz e Graciliano Ramos. Não é de estranhar que num período de grande agitação ideológica, homens de letras expressaram suas convicções, conciliando militância política e literatura de ênfase social, como bem demonstra a produção empenhada do período, representativa de um projeto literário coletivo que agregava a geração que produziu o romance social brasileiro de 30. (BERGAMO, 2008, p. 70)

Dessa forma, os escritores brasileiros e portugueses engajados foram forjados num dos mais turbulentos períodos históricos que a humanidade já teve, visto que seus países também estavam sob o jugo de regimes políticos autoritários, opressores e repressivos. Fato que, segundo Benjamin Abdala Júnior (2007), vai gerar determinados laços de solidariedade entre eles por serem formados na mesma atmosfera ideológica da frente popular antifascista que contagiou os intelectuais do mundo todo na década de 30. Nesse sentido, numa outra obra, o mesmo autor afirma:

\footnotetext{
Nessa situação histórico-cultural formaram-se, com análogas preocupações sociais, as literaturas brasileira e portuguesa da época, cronologicamente: primeiro a brasileira, e, depois, próximo da Segunda Guerra Mundial, a portuguesa. Entre os brasileiros figuram Graciliano Ramos, José Lins do Rego, Jorge Amado, Erico Veríssimo e Amando Fontes, que, como os ficcionistas norte-americanos, influenciaram profundamente a prosa de ficção portuguesa da década de 40, como as produções de Alves Redol, Carlos de Oliveira, Manuel da Fonseca, José Cardoso Pires, Fernando Namora e outros. (ABDALA JÚNIOR, 1981, p.2)
} 
Nesse aspecto, as situações políticas semelhantes nos dois países fizeram com que as afinidades ideológicas (éticas) se convertessem também em afinidades estéticas. Em relação à contribuição dos norte-americanos, lembrada por Benjamin Abdala Júnior, é válido lembrar um depoimento do romancista Vergílio Ferreira, um dos principais nomes do Neorrealismo português, em que ele comenta a importância que teve a leitura dos escritores brasileiros e norte-americanos para a sua formação literária de leitor e escritor:

\begin{abstract}
A minha geração, como é sabido, interessou-se vivamente e foi largamente influenciada pela literatura brasileira - de um Jorge Amado, Graciliano Ramos, Lins do Rego, Erico Veríssimo. A razão desse interesse é perfeitamente explicável: ela tem que ver ainda com determinada situação política. Para uma literatura de imediata acção social como a do famigerado Neorealismo, nós não tínhamos modelos senão os brasileiros. A própria literatura estrangeira nomeadamente americana - que pudesse interessar-nos, dificilmente a poderíamos conhecer senão de traduções brasileiras. Foi assim que eu conheci Por quem os sinos dobram, de Hemingway (ao tempo um livro mais ou menos clandestino), As vinhas da ira, de Steinbeck, Filho nativo, de R. Wrigth, USA, de Dos Passos, etc. Mas outro livro que subterraneamente conhecemos - como esse fundamental La condition humaine de Malraux - nós só os sabíamos ler com os olhos de um imediatismo social e político. A literatura brasileira, portanto, foi a única solução que se nos apresentou. (FERREIRA, 1981, p. 160)
\end{abstract}

O depoimento de Vergílio Ferreira atesta a existência, na primeira metade do século $\mathrm{XX}$, de um grande diálogo intertextual entre os escritores que pautavam seus textos literários aliando uma conduta ética a uma escolha estética, em que os romancistas norte-americanos surgem como pioneiros e os brasileiros aparecem com um papel de destaque dentro do contexto das literaturas de língua portuguesa. Esse diálogo, que ocorre independentemente da nacionalidade do escritor, se constituiu, principalmente, através de uma grande afinidade ideológica, de defesa dos direitos humanos tão ameaçados naquele período, motor da literatura engajada do século XX. Por esse aspecto, pelo fato de o engajamento literário ter se tornado um fenômeno sem fronteiras, ele adquiriu um caráter supranacional, cuja ênfase "está na reivindicação de uma aliança entre arte e sociedade, traduzida em inconformismo e comprometimento social, uma vez que os radicalismos políticos em voga exigiam uma atitude participante do escritor consciente de sua missão" (BERGAMO, 2008, p. 54).

\title{
40 macrossistema literário de língua portuguesa
}

O caráter supranacional que a literatura engajada adquiriu no século XX fez Benjamin Abdala Júnior (2007) pensar na existência de um macrossistema literário no âmbito das literaturas de língua portuguesa. Esse macrossistema englobaria não só as literaturas brasileira e portuguesa, mas também as novas literaturas que surgiram no idioma português a partir dos 
anos 40 nas ex-colônias portuguesas em África: Angola, Cabo Verde, Guiné-Bissau, Moçambique e São Tomé e Príncipe.

O macrossistema literário de língua portuguesa, na concepção de Benjamin Abdala Júnior (2007), constitui-se como um campo comum de contatos entre os sistemas literários nacionais, que se alimenta do passado comum que compartilham e da diversidade que há nas atualizações realizadas em cada uma das literaturas de língua portuguesa.

O passado comum se dá pelo uso da mesma língua, pelas condições históricas das relações entre Portugal e as ex-colônias e das relações entre as próprias ex-colônias, haja vista a grande troca cultural que houve entre o Brasil e as outras ex-colônias, desencadeadas pelo tráfico de escravos. Já as atualizações realizadas dentro de cada sistema literário apresentam aquilo que cada um tem de específico, de diferente do outro dentro do macrossistema, ou seja, são os aspectos particulares de cada um deles, denominados por Abdala Júnior (2007) de "aspectos internos" em contraposição dialética aos "aspectos externos", que correspondem aos aspectos gerais.

Dessa forma, esse passado comum fez com que surgisse um "fenômeno de convergência cultural" (ERVEDOSA, 1979, p. 105) entre os países de língua portuguesa, que explica as afinidades que vão ocorrer no campo literário. A convergência cultural, que Benjamin Abdala Júnior (2007, p. 37) vai renomear de "ecologia cultural", constrói um dinâmico traço de união entre eles e vai favorecer "a circulação de modelos de ruptura" nos momentos de reivindicação e ruptura política e cultural nas ex-colônias portuguesas africanas. Foi o que aconteceu em Angola quando eclodiu o movimento cultural "Vamos descobrir Angola”, embrião do movimento revolucionário que lutaria pela independência política do país. Na origem do movimento, os jovens intelectuais angolanos, espalhados por Luanda e pelas universidades de Coimbra e Lisboa, tinham como exemplo o Modernismo brasileiro de 1922. Nas palavras do angolano Carlos Ervedosa:

Eles sabiam muito bem o que fora o movimento modernista brasileiro de 1922. Até eles havia chegado, nítido, o "grito do Ipiranga" das artes e letras brasileiras, e a lição dos seus escritores mais representativos, em especial de Jorge de Lima, Ribeiro Couto, Manuel Bandeira, Lins do Rego e Jorge Amado, foi bem assimilada.

O exemplo destes escritores ajudou a caracterizar a nova poesia e ficção angolanas, mas é, certamente, num fenómeno de convergência cultural que poderemos encontrar as razões das afinidades das duas literaturas. A mesma amálgama humana, frente a frente nas duas margens do Atlântico tropical, em presença de condições ecológicas quase idênticas, teria de conhecer reações e comportamentos muito semelhantes. (ERVEDOSA, 1979, p.105-106) 
A declaração de Carlos Ervedosa encontra eco na voz de vários escritores angolanos, como, por exemplo, neste depoimento de José Luandino Vieira, feito numa entrevista a Denira Rozário, quando foi questionado sobre as influências que tinha recebido.

Para os escritores nascidos entre 48 e 70, a influência da literatura brasileira é marcante; recebíamos revistas do Brasil e não recebíamos de Portugal. Havia lido Raquel de Queiroz, Jorge Amado, José Lins, Erico Veríssimo e Guimarães Rosa. Já tínhamos lido a geração do Nordeste brasileiro quando começamos a ler a geração neo-realista portuguesa, que entronca com a nossa formação literária dos anos 57. São mais essas duas grandes influências. Os angolanos são mais sensíveis à cultura brasileira, há maior proximidade cultural entre Angola e Brasil. (ROZÁRIO, 1999, p. 194)

O depoimento de Luandino Vieira, além de corroborar a declaração de Carlos Ervedosa sobre a importância dos modernistas brasileiros para a formação dos escritores angolanos da sua geração, também vai ao encontro da ideia do macrossistema literário de língua portuguesa, de Benjamin Abdala Júnior, ao inserir neste diálogo os neorrealistas portugueses, que, como temos visto, dialogam profundamente com a geração modernista brasileira de 30 .

O mesmo processo ocorrido em Angola também se deu em Moçambique no período de formação da literatura nacional, conforme nos atestam as declarações do poeta moçambicano José Craveirinha, em entrevista concedida aos professores Omar Thomaz e Rita Chaves, ao falar sobre os elementos da cultura brasileira conhecidos em Moçambique na época de sua adolescência, e sobre a sua relação com o universo literário.

\footnotetext{
Nós na escola, éramos obrigados a passar por um João de Deus, Dom Dinis etc., os clássicos de lá. Mas chegava uma certa altura que nós nos libertávamos e então enveredávamos para uma literatura "errada": Graciliano Ramos e por aí afora. Tínhamos nossas preferências, e, na nossa escolha, pendíamos desde o Alencar... A nossa literatura tinha reflexos da literatura brasileira. Então, quando chegou o Jorge Amado, estávamos em casa. Jorge Amado nos marcou muito, porque aquela maneira de expor as histórias fazia pensar em muitas situações que existiam aqui...

[...]

Os neo-realistas tiveram muita repercussão aqui. Mas depois veio aquela avalancha de brasileiros: $O$ Cacau e $O$ suor, do Jorge Amado, o Jubiabá... Eu era um dos grandes fãs da Rachel de Queiroz. Eu e muitos, todo o grupo. Íamos para a Livraria Spanos esperar pelo $O$ Cruzeiro, ansiosos pela crônica da Rachel. Quando soube que ela tinha sido contemplada com o Prêmio Camões, fiquei emocionado. (CHAVES, 2005, p. 226-240)
}

Podemos considerar o depoimento de Craveirinha sobre as impressões causadas nos moçambicanos pelos escritores modernistas brasileiros e neorrealistas portugueses como algo extensivo a toda sua geração, conforme é possível perceber pelo uso da segunda pessoa do plural, o que denota a enunciação de um sujeito coletivo. Mas não apenas em Angola e Moçambique há ressonâncias do Modernismo brasileiro. Em Cabo Verde também há marcas explícitas da presença da literatura modernista brasileira no período da reivindicação e 
afirmação cultural, conforme podemos constatar na declaração do sociólogo brasileiro Gilberto Freyre, feita quando esteve em viagem à ex-colônia portuguesa e transcrita pelo cabo-verdiano, Manuel Ferreira.

\begin{abstract}
A linguagem do romancista Jorge Amado, por exemplo, ou a do romancista José Lins do Rego ou a do romancista Erico Veríssimo, ou a do poeta Manuel Bandeira, ou do poeta Jorge de Lima tem hoje imitadores entre os jovens de Cabo Verde, da África, do próprio Portugal. Imitadores que, nessa imitação antes ativa que servil, se utilizam de equivalentes regionais nativos das expressões portuguesas ou mestiças empregadas por vigorosos escritores brasileiros de hoje sob o impacto de condições antes regionais que nacionais da vida brasileira. (FERREIRA, 1967, p. 97-98)
\end{abstract}

Excluindo-se a ideologia luso-tropicalista do autor, que permeia a declaração, e a utilização do termo "imitadores" (apesar de atenuado pela observação de que a imitação é ativa e não servil), incompatível com qualquer pesquisa em literatura comparada na contemporaneidade, a assertiva mostra como a literatura modernista brasileira circulou por Cabo Verde. Além disso, mostra, principalmente, o aspecto mais positivo dessa circulação, colaborando para o surgimento de uma literatura cabo-verdiana moderna que dialogava diretamente com o seu modelo e com o Neorrealismo português, fato que não é difícil de verificar nos textos literários cabo-verdianos escritos no período.

Outro dado importante da declaração de Freyre é a confirmação da existência de um intenso diálogo entre as literaturas brasileira, portuguesa e as novas literaturas em português que estavam surgindo na África, provocado, como já sabemos, pela atmosfera ideológica comum que levou, primeiramente, escritores brasileiros e, depois, os portugueses e africanos ao engajamento literário. Esse dado foi de grande importância para que Benjamin Abdala Júnior (2007, p. 277) concebesse o conceito do macrossistema literário de língua portuguesa, como um campo comum de contatos entre os sistemas literários nacionais, que se alimentam do passado comum que compartilham e da diversidade que há nas atualizações realizadas em cada uma das literaturas de língua portuguesa, de forma que "as experiências de cada país podem ser transmitidas para outro, em face da utilização do mesmo código linguístico, das equivalências culturais e das aproximações históricas."

\title{
5 Considerações finais
}

Ao finalizarmos este texto, fazemos uma ressalva de que, por mais que tenhamos utilizado a palavra "influência", tanto em nosso texto quanto nas citações das quais nos servimos, o sentido com o qual tencionamos empregá-la não era em hipótese alguma com o 
propósito de subordinar uma literatura à outra ou um escritor a outro, tornando um devedor ao outro. O propósito foi de mostrar, por meio do conceito de intertextualidade de Julia Kristeva (1974), que houve uma grande afinidade ideológica que levou a uma afinidade estética entre os escritores da primeira metade do século XX, que tinham preocupações humanas, sociais e políticas semelhantes, que, por sua vez, desencadeou um ruidoso diálogo literário que ainda hoje se faz ouvir o seu eco.

Relembramos que, conforme a conceituação de Kristeva (1974), o texto literário situase numa corrente histórica e social, constituída por textos que o escritor lê e na qual se insere ao reescrevê-los. Nesse sentido, a escrita de um texto literário é a leitura do corpus literário anterior, noção que implica ver o texto como absorção e réplica a outro texto. Nesse aspecto, para Kristeva, a linguagem poética (literária) se constrói por meio de um diálogo de textos em que toda sequência se constrói em relação à outra, oriunda de um outro corpus, de forma que ela é duplamente orientada: primeiro para o ato de reminiscência, que é a evocação de outra escrita; segundo, para o ato de intimação, que é a transformação da escrita evocada. Dessa forma, um livro remete a outros livros, o que confere a eles um novo modo de ser, elaborando também a sua própria significação.

Além disso, tínhamos o intento de mostrar, também, que houve sim escritores pioneiros, que forneceram modelos e caminhos que foram seguidos por outros, mas nem por isso a literatura desses outros escritores que vieram depois se tornou uma mera cópia dos primeiros, totalmente devedora deles.

Dessa forma, pensamos a questão da influência literária não como algo que possui a originalidade e a imitação em seus polos, mas, sim, conforme pensa Benjamin Abdala Júnior (1981), na esteira do pensamento de Kristeva (1974), como um processo de transferência, distribuição e desenvolvimento de formas literárias que se realiza através da intertextualidade, por meio da qual um texto é elaborado como resultado de outros textos, através de um trabalho poético de absorção e transformação, pois "ninguém cria do nada" (ABDALA JÚNIOR, 2007, p.44) e todo escritor se insere numa tradição literária existente e cria a partir dela.

Por essa perspectiva, todo texto literário em português é escrito a partir de uma tradição literária preexistente em língua portuguesa que, por sua vez, insere-se na tradição literária ocidental. Dessa forma, não há dependência e nem imitação entre as obras literárias engajadas escritas em língua portuguesa no século passado que apresentam determinados elementos comuns, como a temática e as técnicas narrativas. Nesse sentido, "o que ocorre 
normalmente é a adoção de estratégias discursivas comuns reconhecíveis em mais de um sistema literário, visto que a identidade linguística e cultural torna inevitável o contato" (BERGAMO, 2008, p. 187).

Assim, conforme bem observou Benjamin Abdala Júnior (2003, p. 67), há “processos de apropriação dentro das literaturas de língua portuguesa” que ocorrem através do "aproveitamento de sugestões temáticas e de processos narrativos, no terreno literário, e como expressão de afinidades eletivas, no campo político" (BERGAMO, 2008, p. 109), pois, no caso da literatura engajada, os escritores "estão comprometidos com a transformação e suas perspectivas críticas não lhes permitem descartar a experiência alheia" (ABDALA JÚNIOR, 2007, p. 39) com o intuito de alcançarem a conscientização dos seus leitores.

O diálogo intertextual entre os escritores engajados de língua portuguesa ocorrido a partir da década de 30 é desencadeado por uma afinidade ideológica entre os escritores que se viam, primeiramente, como companheiros que estavam numa mesma trincheira, lutando contra a alienação, a violência, a injustiça e a miséria humana, com o objetivo de tornar o mundo um pouco melhor, tendo como arma a palavra literária. Nesse sentido, vale lembrar uma declaração do romancista brasileiro Erico Veríssimo sobre um encontro que teve com escritores portugueses durante uma viagem realizada a Portugal em 1959.

Estou sentado entre dois portugueses que admiro e estimo, e que, após alguns minutos de conversação, já posso considerar meus amigos: Maria Lamas e Vergílio Ferreira. Eu conhecia a odisséia dessa brava intelectual portuguesa perseguida pela polícia salazarista e que tem passado alguns anos de sua vida em forçados exílios. É uma senhora de meia-idade, de pele trigueira e cabelos grisalhos, belas feições serenas, manso o gesto, suave a voz... Quanto a Vergílio Ferreira, que terá pouco mais de quarenta anos, é um homem cuja face inspira simpatia e confiança. Fala pouco e sabe escutar. Nota-se-lhe nos olhos uma expressão de desalento, de desesperança. Conheço dele apenas um livro, um de seus primeiros romances, ainda do tempo em que os críticos lhe haviam pespegado o rótulo de neo-realista. É possível que Ferreira tivesse pertencido a essa escola, mas nos seus últimos romances tem-se agora revelado um escritor aberto aos problemas existenciais do homem. [...]. Não sei, não pergunto e creio até que não desejo saber se Vergílio Ferreira leu algum de meus livros. Estou certo de que entre os intelectuais portugueses que me têm recebido tão cordialmente haverá muitos provavelmente a maioria - que nunca abriram um livro de minha autoria ou, se abriram, não gostaram ou ficaram indiferentes. Nada disso, porém, me preocupa. O importante é que eles parecem ver em mim um companheiro de lutas democráticas. Isso, sim, me alegra. (VERISSIMO, 1976, p. 210-211)

Essa afinidade ideológica entre companheiros de lutas democráticas levou os romancistas engajados brasileiros e portugueses a uma afinidade estética que resultou na apropriação de temas e técnicas narrativas pelos segundos em relação aos primeiros, e assim compartilharam "modelos semelhantes de articulação literária" (ABDALA JUNIOR, 2007, p. 65). Dessa forma, os escritores portugueses debruçaram-se sobre a realidade social e política portuguesa, abordando temas que diziam respeito à vida e ao desenvolvimento da nação, 
assim como os brasileiros haviam feito alguns anos antes, utilizando-se de técnicas narrativas semelhantes.

Do mesmo modo, posteriormente, os jovens escritores africanos de língua portuguesa, sobretudo os angolanos, cabo-verdianos e moçambicanos, vão se identificar com a literatura produzida pelos modernistas brasileiros e neorrealistas portugueses. De modo que vão utilizar as formas literárias destes como modelos para retratar suas terras e suas gentes e, principalmente, para construir uma literatura nacional e também uma nação, por meio do processo de leitura do corpus literário anterior de língua portuguesa, de absorção e réplica a outro texto, que caracteriza a intertextualidade como um diálogo entre textos em que toda sequência se constrói em relação à outra sequência.

\section{Referências}

ABDALA JÚNIOR, Benjamin. A escrita Neo-realista. São Paulo: Ática, 1981. . De vôos e ilhas: literatura e comunitarismos. Cotia: Ateliê Editorial, 2003. . Literatura, história e política. 2. ed. Cotia: Ateliê Editorial, 2007.

ALMEIDA, António Ramos de. O romance brasileiro contemporâneo através de seus principais intérpretes. Sol Nascente, Porto, dez. 1965.

BAKHTIN, Mikhail. Problemas na poética de Dostoievski. Trad. Paulo Bezerra. São Paulo: Forense, 1997.

BERGAMO, Edvaldo. Ficção e convicção: Jorge Amado e Neo-realismo português. São Paulo: Editora da Unesp, 2008.

CANDIDO, Antonio. A educação pela noite e outros ensaios. 5. ed. Rio de Janeiro: Ouro sobre Azul, 2006.

Literatura e sociedade. 8. ed. São Paulo: T. A. Queiroz, 2000.

CHAVES, Rita. Angola e Moçambique: experiência colonial e territórios ocupados. Cotia: Ateliê Editorial, 2005.

DENIS, Benoît. Literatura e engajamento: de Pascal a Sartre. Bauru/SP: Edusc, 2002.

ERVEDOSA, Carlos. Roteiro da literatura angolana. 2. ed. Lisboa: Edições 70, 1979.

FERREIRA, Manuel. A aventura crioula. Lisboa: Ulisséia, 1967.

FERREIRA, Vergílio. Um escritor apresenta-se. Lisboa: Imprensa Nacional/Casa da Moeda, 1981. 
KRISTEVA, Julia. Introdução à semálise. Trad. Lúcia Helena França Ferraz. São Paulo: Perspectiva, 1974.

MONTEIRO, Adolfo Casais. O romance (teoria e crítica). Rio de Janeiro: José Olympio, 1964.

ROZÁRIO, Denira. Palavra de poeta: Cabo Verde e Angola. Rio de Janeiro: Bertrand do Brasil, 1999.

SARTRE, Jean-Paul. Que é literatura? 3. ed. Trad. Carlos Felipe Moisés. São Paulo: Ática, 2006.

VERISSIMO, Erico. Solo de clarineta. vol. 2. Porto Alegre: Globo, 1976.

WATT, Ian. A ascensão do romance. Trad. Hildegard Feist. São Paulo: Companhia das Letras, 1990.

WILLIANS, Raymond. Marxismo e literatura. Trad. Waltensir Dutra. Rio de Janeiro: Zahar, 1979. 